\title{
Guidance of Farmers in Performing Integrated Combation of Pests in the Technical Irrigation Area in South Sulawesi
}

\author{
Faizal Amir, Mithen Lullulangi, Haruna Haji La Tang, Marsus Suti \\ Engineering Department, Universitas Negeri Makassar, Makassar, Indonesia \\ Email address: \\ faizalamir64@unm.ac.id (F. Amir), mithen@unm.ac.id (M. Lullulangi), harunaoto6@gmail.com (H. H. La Tang), \\ marsus.unanda301260@gmail.com (M. Suti)
}

\section{To cite this article:}

Faizal Amir, Mithen Lullulangi, Haruna Haji La Tang, Marsus Suti. Guidance of Farmers in Performing Integrated Combation of Pests in the Technical Irrigation Area in South Sulawesi. American Journal of Environmental Protection. Vol. 8, No. 5, 2019, pp. 104-108. doi: 10.11648/j.ajep.20190805.12

Received: October 21, 2019; Accepted: November 12, 2019; Published: November 19, 2019

\begin{abstract}
This study aims to find: training models, teaching materials, and methods for socializing and implementing models that can be a reference used to train farmers to carry out integrated pest control (IPM) as an effort to increase production and sustainable income in technical irrigation areas. Research location in the technical irrigation area of South Sulawesi Province. Research respondents were selected by purposive method, as many as 300 people. The research variables are: training model, teaching material, socialization method, and application of integrated pest control model. Data collection is done by giving questionnaires to respondents. Validation of models and teaching materials is carried out by relevant experts. The data analysis technique used is descriptive qualitative analysis. The results of the study are: Integrated pest control training model in technical irrigation areas, consisting of seven steps, namely: 1) needs analysis, 2) determining teaching material, 3) formulating objectives, 4) developing and validating materials, 5) preparing tests, 6) carry out training, and 7) conduct an evaluation.
\end{abstract}

Keywords: Training Model, Integrated Pest Eradication, Technical Irrigation Area, Teaching Material, and Farmers

\section{Introduction}

The Technical Irrigation Area is a sub system of the overall ecosystem structure, and is a built environment for farmers. The area of Technical Irrigation, a state investment that is of enormous value, is a target area for farmers to try farming. The Law of the Republic of Indonesia Number 32 of concerning Environmental Protection and Management explains that everyone has the right to a good environment and must maintain and preserve it [1]. Affandi, said that: Environment, which is a unity of space with all objects, power, conditions, and living things, including humans and their behavior, which affects the continuity of life and welfare of humans and other living things, due to the fact that shows that the level of environmental damage is very high and tend to get higher, relatively easy to find. [2].

Minister of the Environment Regulation No. 01, About Management of Water Pollution Control explained that the use of chemicals for controlling insects, pests, weeds, and fungi in agricultural areas has increased the productivity of farming [3]. Brundtland, states that excessive use of chemicals threatens the lives of humans and other species [4]. Ithof said that: One of the efforts of humans in the context of caring for the environment is to limit human behavior in each of its activities in accordance with the contents contained in the Law on the Environment, so that between humans and nature there is a balance that is always maintained and preserved. Human behavior that always cares about the environment, one aspect, can be realized [5] Muhammad Ardi's, research about several factors that influence the behavior of farmers in farming and preserving the environment in several irrigation areas in South Sulawesi Province [6]. The results showed that the behavior of farmers is strongly influenced by: issues of knowledge, attitudes, and motivation to care for the environment. Research by Muhammad Ardi and Faizal Amir, in the wet farming area of Soppeng Regency, found that environmental knowledge, attitudes, and behavior of farmers preserving the environment are classified as regions [7].

Goad in Hanrahmawan, developed a training model 
through several stages whose cycle consisted of: (a) training needs analysis, (b) designing training approaches, (c) developing training materials, (d) conducting training, and (e) evaluating and repair training [8]. Banathy in Sanjaya, designed a learning program into six stages as follows: (a) analyzing and formulating objectives, (b) formulating test criteria, (c) analyzing and formulating learning activities, (d) designing systems, (e) implement, and (f) make improvements and changes based on evaluation [9]. Dick and Carey in Sanjaya (2011) designed a training model that began with: (a) identification of objectives, (b) formulating tests, (c) developing learning strategies according to objectives, and (d) conducting evaluations [9]. Soerjani, et al. states that the environment is a living system in which there is human intervention in the ecosystem [10].

Irrigation, according to Hariyanto, is networks are needed by farmers who need available resources (human, equipment, materials). To place resources, we need a model that influences the implementation of the use of irrigation in systematic detail, so that it can predict the running of the program. [11]. Pasandaran, states that the effort that needs to be done in the management of irrigation water is the regulation and provision of water according to the needs of the plant or farming effort being pursued [12]. Anwar Adilaga, states that conservation farming is a farming business that pays attention to erosion prevention, such as: (1) maintaining the recycling of soil organic matter so that it can be maintained at a level that benefits plants, (2) maintaining and increasing soil fertility by providing fertilizer in accordance with the needs of farming and soil conditions, and (3) using land according to his ability [13]. Marchel, states that farming is the study of how to allocate resources owned by farmers to run effectively and efficiently, and utilize these resources in order to obtain the highest profit [14].

Oka, states that integrated pest control (IPM) or integrated pest control (IPC) is pest management that uses all appropriate techniques and methods in harmonious and harmonious ways and maintains pest populations below the level that causes economic damage. in environmental conditions and population dynamics of the pest species concerned [15]. Marry and Robert, states that integrated pest control (IPM) should be understood as an ecology-based pest control strategy that focuses on natural mortality factors such as natural enemies and weather and seeks to control tactics that disrupt these factors to a minimum [16]. Untung (2006) states that the use of pesticides is the last alternative. Furthermore it is said that the application of IPM refers to four principles, namely: (1) Healthy plant cultivation, (2) Conservation of natural enemies, (3) Regular ecosystem monitoring, and (4) Farmers as determinants of control decisions or as IPM experts [17].

\section{Research Methods}

The research approach is research development. The stages of the research are as follows: (1) conducting survey research to study and find training models and teaching materials in conducting integrated pest eradication; (2) developing teaching materials found relating to the eradication of integrated pests as an effort to increase farm production and sustainable farmers' income in technical irrigation areas. The research location is the technical irrigation area of South Sulawesi Province. The sample area was chosen by purposive sampling method, namely Saddang irrigation area, Langkemme irrigation area, and Bantimurung irrigation area. The research respondents were selected by purposive method, as many as 300 people. Data collection is done by giving questionnaires. Validation of models and teaching materials is carried out by relevant experts. Analysis of the data used is qualitative descriptive analysis.

\section{Results and Discussion}

\subsection{Training Model that Can Be a Reference in Fostering Farmers Conducting IPM as an Effort to Increase Production and Income in a Sustainable Manner}

\subsubsection{Conduct a Needs Analysis}

The results of an analysis of 300 samples showed that $17.33 \%$ expressed strongly agree, and $82.67 \%$ agreed. It can be concluded that conducting a needs analysis is the first step in determining a training model. Analysis of training needs is very important to know before designing training. Needs analysis is the basis for developing training materials for farmers conducting IPM. These findings are in line with Hanrahmawan's, model which states that needs analysis is the first step in formulating a training model [8].

\subsubsection{Determine Teaching Material}

The analysis of 300 samples showed that $30 \%$ expressed strongly agree, strongly agreed, $68 \%$ agreed, and $2 \%$ expressed doubt. It can be concluded that determining the teaching material is the second step in determining the training model. Training material is the main and important element in a training activity for farmers conducting IPM. This finding is in line with Nadler, who developed a training model known as The Critical Events Model (CEM) or called the open training model, in which one step is to determine teaching material [18].

\subsubsection{Formulate Learning Objectives}

The analysis of 300 samples showed that $18 \%$ stated strongly agree stated strongly agreed, $73.34 \%$ stated agreed, $4 \%$ expressed doubt, and $0.33 \%$ stated disagreed. It can be concluded that formulating learning objectives is the third step in determining the training model. The learning objectives are the directors in a training activity for farmers conducting IPM. This finding is in line with Djudju Sudjana's statement, which states that one of the steps in determining the training model is to formulate learning objectives [19].

\subsubsection{Develop and Validate Material}

The results of an analysis of 300 samples showed that $22.33 \%$ stated strongly agreed stated strongly agreed, $78 \%$ 
stated agreed, $2.67 \%$ expressed doubt, and $1.33 \%$ stated disagreed. It can be concluded that developing and validating teaching materials is the fourth step in determining the training model for farmers conducting IPM.

\subsubsection{Formulate and Arrange Tests}

The results of an analysis of 300 samples showed that $22.33 \%$ stated strongly agreed stated strongly agreed, $75.67 \%$ stated agreed, and $2 \%$ expressed doubt. It can be concluded that formulating and compiling tests is the fifth step in determining the training model for farmers conducting IPM. The findings of this study are in line with what was stated by Djudju Sudjana, which states that one of the steps in determining the training model is to formulate and arrange tests so that the success of the training can be measured [19].

\subsubsection{Carry Out Counseling and Training}

The results of an analysis of 300 samples showed that as many as $26 \%$ expressed strongly agree stated strongly agreed $73 \%$ stated agreed, and $1 \%$ stated disagreed. It can be concluded that conducting counseling and training is the sixth step in determining the training model for farmers conducting IPM. These findings are in line with the explanation of Hanrahmawan, which states that one of the steps in determining the training model is conduct the training [8].

\subsubsection{Conduct an Evaluation}

The analysis of 300 samples shows that $24 \%$ expressed strongly agree, strongly agree, and $76 \%$ agree. It can be concluded that conducting an evaluation is a step in determining the training model for farmers conducting IPM. These findings are in line with the model of Hanrahmawan, and Djudju Sudjana, which states that one of the steps in determining the training model is to conduct an evaluation. The evaluation aims to measure the success of training participants while simultaneously measuring the effectiveness and efficiency of the training model applied [8], [19].

\subsection{Teaching Material Needed by Farmers in Conducting IPM in an Effort to Increase Production and Income in a Sustainable Manner}

\subsubsection{Material on Integrated Pest Eradication}

The results of an analysis of 300 samples showed that $17.67 \%$ stated strongly agree stated strongly agreed, $79.67 \%$ stated agreed, and $2.66 \%$ expressed doubt. It can be concluded that integrated pest eradication material in wet farming areas is needed by farmers in conducting IPM. The material, it is important given to farmers so that their understanding of pest eradication in an integrated manner can increase.

\subsubsection{Material About the Types of Pesticides}

The analysis of 300 samples shows that $21 \%$ expressed strongly agree, strongly agreed, $75 \%$ stated agree, and $4 \%$ expressed doubt. It can be concluded that the material about the types of pesticides is needed by farmers in conducting
IPM. The material is very important given to farmers so that farmers have insight into the types of pesticides in farming.

\subsubsection{Material About Plants that Can Be Used as Natural Pesticides}

The results of an analysis of 300 samples showed that $17.67 \%$ stated strongly agree stated strongly agreed, $78.67 \%$ stated agreed, and $3.66 \%$ expressed doubt. It can be concluded that material about plant types that can be used as natural pesticides is needed by farmers in conducting IPM in an effort to increase production and income in a sustainable manner in technical irrigation areas. The material is very important given to farmers so that farmers can take advantage of farming.

\subsubsection{Material About the Dose of Chemical Pesticides}

The results of the analysis of 300 samples showed that $27.33 \%$ stated strongly agreed, strongly agreed, and $72.67 \%$ agreed. It can be concluded that the material about the dose of chemical pesticides is needed by farmers in conducting IPM. The material is very important given to farmers so that farmers do not use it wrongly in farming.

\subsubsection{Material About Environmentally Friendly Pesticides}

The analysis of 300 samples shows that $32 \%$ expressed strongly agree, strongly agreed, $65 \%$ agreed, and $3 \%$ expressed doubt. It can be concluded that materials about environmentally friendly pesticides are needed by farmers in conducting IPM. The material is very important given to farmers so that farmers do not choose chemical pesticides in farming.

\subsubsection{Material on How to Use Pesticides}

The analysis of 300 samples showed that $29 \%$ agreed strongly, and $71 \%$ agreed. It can be concluded that the material on how to use pesticides is needed by farmers in conducting IPM. The material is very important given to farmers so that farmers do not use chemical pesticides wrong in farming.

\subsubsection{Material About Pests and Types of Pests}

The results of the analysis of 300 samples showed that as much as $41.33 \%$ stated strongly agreed stated strongly agreed, and 58.67 stated agreed. It can be concluded that the material about pests and types of pests needed by farmers in conducting IPM. The material is very important given to farmers so that farmers can identify pests and types of pests in farming.

\subsection{Methods, Socializing and Applying Training Models for Farmers in Conducting IPM}

\subsubsection{Introduce the Contents of the Training Material}

The results of an analysis of 300 samples showed that $32.33 \%$ stated strongly agreed, strongly agreed, $63.67 \%$ stated agreed, and $4 \%$ expressed doubt. It can be concluded that introducing the contents of the training material to relevant stakeholders is the first step that must be taken in socializing and implementing a training model for farmers in 
conducting IPM.

\subsubsection{Communicating the Objectives and Benefits of the Training}

The results of an analysis of 300 samples showed that $33 \%$ stated strongly agree stated strongly agreed, 64\% stated agreed, and 3\% expressed doubt. It can be concluded that conveying the objectives and benefits of training to relevant stakeholders is the second step that must be taken in socializing and implementing a training model for farmers in conducting IPM.

\subsubsection{Selecting Training Participants}

The results of an analysis of 300 samples showed that $22.67 \%$ stated strongly agreed stated strongly agreed, $75.67 \%$ stated agreed, and $1.66 \%$ expressed doubt. It can be concluded that selecting training participants is the third step that must be taken in socializing and applying training models for farmers in conducting IPM.

\subsubsection{Determine the Training Schedule and Place}

The results of the analysis of 300 samples showed that $32.33 \%$ stated strongly agreed stated strongly agreed, $61 \%$ stated agreed, and $6.67 \%$ expressed doubt. It can be concluded that determining the schedule and place of training is the fourth step that must be taken in socializing and implementing a training model for farmers in conducting IPM.

\subsubsection{Determine the Number of Training Participants}

The results of an analysis of 300 samples showed that $41.33 \%$ stated strongly agreed, strongly agreed, 54.67\% stated agreed, and $4 \%$ expressed doubt. It can be concluded that determining the number of training participants is the fifth step that must be taken in socializing and implementing a training model for farmers in conducting IPM.

\subsubsection{Provide Direction to the Trainees}

The results of an analysis of 300 samples showed that $39 \%$ stated strongly agree stated strongly agreed, 55\% stated agreed, and $6 \%$ expressed doubt. It can be concluded that giving direction to trainees is the sixth step that must be taken in socializing and implementing training models for farmers in conducting IPM.

\subsubsection{Distributing Material to Trainees}

The results of an analysis of 300 samples showed that as much as $40.67 \%$ expressed strongly agree stated strongly agreed, and $59.33 \%$ stated agreed. It can be concluded that distributing material to trainees is the seventh step that must be taken in socializing and applying training models for farmers in conducting IPM.

\subsubsection{Carry out Training}

The analysis of 300 samples shows that $43 \%$ strongly agree agree strongly agree, and $57 \%$ agree. It can be concluded that conducting training to trainees is the eighth step that must be carried out in socializing and applying training models for farmers in conducting IPM.

\subsubsection{Conduct an Assessment}

The analysis of 300 samples shows that 52\% strongly agree agree strongly agree, and $48 \%$ agree. It can be concluded that conducting an assessment is the ninth step that must be done in socializing and implementing a training model for farmers in conducting IPM.

\subsubsection{Conduct an Evaluation}

The results of an analysis of 300 samples showed that $41.33 \%$ stated strongly agreed stated strongly agreed, $56.67 \%$ stated agreed, and $2 \%$ expressed doubt. It can be concluded that conducting an evaluation is the tenth step that must be carried out in socializing and implementing a training model for farmers in conducting IPM.

\section{Conclusion}

The conclusions of this study are: 1) Training model that can be a reference in training farmers to carry out integrated pest control in an effort to increase production and income in a sustainable manner in technical irrigation areas, consisting of several steps, namely: conducting needs analysis, determining teaching material, formulating learning objectives, developing and validating teaching materials, formulating and compiling tests, conducting counseling and training, and conducting evaluations. 2) Teaching materials needed by farmers to improve environmental quality in a sustainable manner in technical irrigation areas, consisting of: integrated pest control knowledge, knowledge of types of pesticides, knowledge of plant types that can be made into natural pesticides, knowledge of the dose of chemical pesticides, knowledge of environmentally friendly pesticides, knowledge of how to use pesticides, knowledge of the impact of excessive use of pesticides on the physical environment, knowledge of the impact of the use of pesticides on health, and knowledge of the types of pests. 3) Steps taken to disseminate and implement training models for farmers to carry out integrated pest control in an effort to increase production and income in technical irrigation areas, consisting of: introducing the contents of training materials, conveying the objectives and benefits of training, selecting training participants, determining the schedule and place of training, determine the number of trainees, give direction to trainees, distribute materials to trainees, conduct training, conduct assessments, and conduct evaluations.

\section{Acknowledgements}

The authors thank each of them to: 1) Chancellor of Makassar State University as Trustee of research and community service for Makassar State University, 2) Directorate of Research and Community Service Community Directorate General of Research and Development Strengthening Ministry of Research, Technology and Higher Education for funds provided for lecturer research guidance at tertiary institutions3) Chairperson and Secretary of the Institute of Research and Community Service (LP2M) 
Makassar State University as the person in charge and director of research activities at Makassar State University, 4) The Regents of the Regional Head as the person in charge of the occupied territory conduct research, with their permission to conduct research, 5) Heads of Services in each Regency occupied by researching, on their instructions and direction in collecting research data, and 6) All parties who cannot be mentioned one by one who have contributed to the research $n$ this.

\section{References}

[1] Undang-Undang Republik Indonesia Nomor 32 tahun (2009) tentang Perlindungan dan Pengelolaan Lingkungan Hidup.

[2] Affandi, Leonardo. (2017). Hubungan Manusia dan Lingkungan Sekitar. Published by Leonardoaffandi. https://leonardoaffandi.wordpress.com

[3] Peraturan Menteri Negara Lingkungan Hidup No. 01 Thn (2010) Tentang Tatalaksana Pengendalian Pencemaran Air.

[4] Brundtland, Harlem Gro; et al. (1988). Our Common Future. Hari Depa Kita Bersama. Komisi Dunia untuk Lingkungan dan Pembangunan. (World Commission on Environment and Development). Jakarta: PT. Gramedia.

[5] Ithof, Mohammd. (2018). Minimnya Tingkat Kesadaran dan Akuntabilitas Masyarakat Terhadap Lingkungan Sekitar. Project Artikel Peduli Lingkungan. https://www.researchgate.net/publication/329656390

[6] Muhammad Ardi. (2012). Beberapa Faktor yang Mempengaruhi Perilaku Petani dalam Berusaha Tani dan Melestarikan Lingkungan Hidup pada Beberapa Daerah Irigasi di Provinsi Sulawesi Selatan. Makassar: Lembaga Penelitian Universitas Negeri Makassar.

[7] Muhammad Ardi dan Faizal Amir. (2015). Pengetahuan dan Sikap Petani Berusahatani dan melestarikan lingkungan pada daerah pertanian basah, Daerha Pertanian Tegalan, dan Daerah Penyangga $i$ Kabupaten Soppeng. Makassar: Lembaga Penelitian UNM.
[8] Hanrahmawan, Fitroh. (2010). "Revitalisasi Manajemen Pelatihan Tenaga Kerja" (Studi Kasus pada Balai Latihan Kerja Industri Makassar). Jurnal Administrasi Publik.

[9] Sanjaya, Wina. (2011). Strategi Pembelajaran Berorientasi Standar Proses Pendidikan. Jakarta: Kencana Prenada Media.

[10] Soerjani, M., Ahmad, R., \& Munir. (2010). Lingkungan, Sumberdaya Alam dan Kependudukan dalam Pembangunan. Jakarta: Universitas Indonesia.

[11] Hariyanto. (2018). Analisis Penerapan Irigasi untuk Peningkatan Hasil Pertanian di Kecamatan Cepu Kabupaten Blora. Reviews in Civil Engineering, v. 02, n. 1, p. 29-34, Maret 2018 29. jurnal.untidar.ac.id/index.php/civilengineering.

[12] Pasandaran, E. (1991). Irigasi di Indonesia. Jakarta: Lembaga Penelitian Pendidikan dan Penerangan Ekonomi dan Sosial (LP3ES).

[13] Anwar Adilaga. (1982). Ilmu Usahatani. Bandung: Penerbit Alumni.

[14] Marchel Christian Pangkey, Vecky A. J. Masinambow, dan Albert T. Londa, (2016). Comparison of the Coconut Farmers, Income in Minahasa District South (A Case Stdy in the Village Ongkaw I and Rural Districts Tiniawangko Sinonsayang). Jurnal Berkala Ilmiah Efisiensi Volume 16 No. 02 Tahun 2016.

[15] Oka, Ida Nyoman. (1998). Pengendalian Hama Terpadu dan Implementasinya di Indoesia. Yogyakarta: Gdjahmada University Press.

[16] Marry \& Robert, V. D. (2002). Pengendalian Hama Terapadu, Sebuah Pengantar. Yogyakarta: Penerbit Kanisius.

[17] Untung, K. (2006). Pengantar Pengelolaan Hama Terpadu. Yogyakarta: Gadjah Mada University Ptress.

[18] Nadler, L. \& Nadler, Z. (1982). Designing Training Programs: The Critical Events Model. Houston, Texas: Gulf Publishing Co.

[19] Djudju Sudjana. (1993). Metode dan Teknik Pembelajaran Partisipatif dalam Pendidikan Luar Sekolah. Bandung: Nusntara Press. 